E N T R E V I S T A

\title{
ENTREVISTA COM LUIZ FELIPE DE ALENCASTRO
}

\author{
Interview with Luiz Felipe de Alencastro
}

\author{
CONCEDIDA A ALEXANDRE MORELI, \\ BERNARDO BUARQUE E MARCO AURÉlIO VANNUCCHI
}

São Paulo, 6 de julho de 2015

http://dx.doi.org/10.1590/S0103-21862016000100016

Alexandre Moreli, Bernardo Buarque e Marco Aurélio Vannucchi são professores da Escola de Ciências Sociais (CPDOC) da Fundação Getúlio Vargas (FGV) (alexandre.moreli@fgv.br, bernardo.hollanda@fgv.br e marco.vannucchi@fgv.br).

Os entrevistadores agradecem a Raissa Pose Pereira, lago Gama Drumond e Rafaela Maia Carvalho pelo apoio na redação das notas explicativas presentes no texto. 
trajetória acadêmica de Luiz Felipe de Alencastro, catarinense de Itajaí nascido
em 1946, tem-se desenvolvido entre o Brasil e a França. Graduado em Ciência Política pela Universidade de Aix-en-Provence (1970) e doutor em História pela Universidade de Paris X (1986), Alencastro ensinou na Universidade de Paris VIII (1974-1986), na Universidade de Rouen (1977-1986) e, finalmente, na Universidade de Paris IV, ou Paris-Sorbonne (2000-2014). Na Sorbonne, onde é professor emérito, orientou diversas dissertações e teses de alunos brasileiros, franceses e de outras nacionalidades sobre História do Brasil, da América Latina e da África. No Brasil, entre 1986 e 1999, foi professor na UNICAMP e pesquisador do CEBRAP. Atualmente é professor da Escola de Economia de São Paulo (EESP) da Fundação Getulio Vargas (FGV). É autor de uma importante obra sobre o Brasil Colônia e Império, na qual se destaca $O$ trato dos viventes (2000), um estudo sobre a escravidão brasileira enquadrada no espaço do Atlântico Sul. Alencastro também mantém uma atuação como intelectual público, participando da vida política brasileira e do debate sobre temas da atualidade, especialmente por meio da imprensa.

\section{Você é catarinense, nascido em 1946. Poderia nos falar sobre suas origens familiares?}

Nasci em Itajaí, cidade que tinha 30 mil habitantes, porto do Vale do Itajaí. Meu pai era de uma família de Goiás Velho, se formou no Rio e foi para lá depois da Revolução de 1930. A família dele era aliada dos Caiado, e um primo dele, que era funcionário do Correio Federal, foi transferido para Santa Catarina a pedido do Pedro Ludovico, da nova ordem. Minha mãe vinha de uma família cujas origens eram alemãs e açorianas.

\section{Como foi sua vivência em Santa Catarina?}

Em 1951 foi o centenário de Joinville, que assim como Blumenau e Brusque foi um enclave de imigrantes alemães fundado no fim do tráfico negreiro. Houve várias comemorações 
por ali nos anos 50. Meus avós, de Goiás Velho, vinham nos visitar. Era uma viagem longa, com trocas de aviões e paradas pelos aeroportos. Eles ficavam surpreendidos com aquele ambiente de gente do povo falando alemão. 0 contraste cultural do Brasil, das diferenças dentro do país, impressionava meus avós, e a reação deles me impressionou também. Outra coisa que me marcou foi a proximidade social que existia na região de Itajaí, onde havia pobres, claro, mas muito pouca gente vivendo na miséria, como também não havia gente muito rica.

\section{Sobre sua formação escolar, o que poderia nos contar?}

Estudei no Colégio Catarinense, dos jesuítas, em Florianópolis. Tive como professor o padre João Alfredo Rohr, ${ }^{1}$ que foi pioneiro no estudo dos sambaquis e dos paleoindígenas. Ele incentivou a legislação para preservar os sambaquis como local de pesquisa arqueológica e criou um museu no Colégio. 0 internato tinha um regime severo, aula de manhã e estudo a tarde inteira, acordando todo dia cedo para ir à missa e tal. É um mundo que não existe mais.

Cresci lá durante o governo do Juscelino, que foi o momento em que o Brasil foi mais otimista. Houve a indústria automobilística, a construção de Brasília, um regime democrático até então inédito. Em seguida, mudamos para Brasília. Fomos para Goiânia primeiro, em família, e meu pai foi para capital federal. Ele era pediatra.

\section{A formação dele foi na Faculdade de Medicina do Rio de Janeiro.}

Sim, ele se formou no final dos anos 1920, foi das primeiras turmas formadas no prédio da Praia Vermelha. Quando chegou a Brasília vindo de Santa Catarina, ficou tocado com a miséria dos candangos. As condições sociais existentes na construção de Brasília constituem um episódio mal conhecido. lam chegando trabalhadores e famílias em situação precária, sem alojamento. Uma vez, num posto de gasolina perto de Brasília, vi um "pau-de-arara" com pessoas que não saíam do caminhão e bebiam água de uma mangueira esticada para cima da caçamba. Vinha gente do Nordeste, mas também de Minas e Goiás, onde as pessoas pobres em geral não passavam forme, porque viviam na beira do rio, comendo peixe, banana e o fruto que aparecia, com a pequena rocinha ali. De repente, iam parar numa favela em Brasília, sem nada em volta, sem poço nem água corrente. Antes do lago Paranoá encher e aquelas árvores crescerem, o clima de Brasília era muito mais seco. Havia a desidratação, que aumentava a mortalidade infantil. Meu pai dirigia o Pronto Socorro Infantil do Hospital de Base e ficou impressionado com essa precariedade social. 


\section{Foi em Brasília que se deu seu ingresso na universidade.}

Sim. Prestei vestibular para a UnB, e entrei no começo de março de 1964, fui da segunda turma. Era um sistema diferente, que o Anísio Teixeira e o Darcy Ribeiro, fundadores da UnB, tinham criado. Era parecido com o sistema francês. Todo mundo fazia todas as disciplinas de Ciências Humanas e, mais adiante, você escolhia. Podia ir para Direito, para Economia. Só Arquitetura tinha um ensino separado.

\section{Como era o clima político em Brasília e na UnB em meados dos anos 1960 ?}

Desde 1963, com o retorno do presidencialismo, nós estávamos numa grande tensão. Quando veio o golpe de 1964, ficamos perplexos. Jango tinha ido para o Rio Grande do Sul. A gente não sabia o que ia acontecer. No meio tempo, com outros companheiros, integramos a direção da Feub, Federação de Estudantes Universitários de Brasília, e todos nós ficamos expostos. Criaram vários IPMs que pegavam a UnB toda, sobre a UNE, sobre o método Paulo Freyre, sobre uma declaração que nós demos condenando o "terrorismo cultural" na UnB. Tinha a PM, tinha o Exército, tinha a Marinha, e a gente era "freguês" desses IPMs todos... Fui preso e solto logo depois. Mas era igual a continuar preso, você ia para casa, naquelas superquadras isoladas de Brasília, tinha um soldado embaixo, e um jipe com um militar na esquina. A cidade era meio vazia, com um aeroporto pequeno e militarizado, com uma estrada que ia para o Rio, via Belo Horizonte, e outra que ia para São Paulo, via Goiânia. 0 ambiente era lúgubre na cidade, porque a maioria dos funcionários públicos e dos habitantes era juscelinista e janguista, e temia perseguições.

\section{Já se sentia o estado de exceção.}

Eu não sofri violências físicas, mas um dia, num interrogatório no Batalhão da Guarda Presidencial, eu vi o pai de um amigo meu, polonês, que havia sido torturado em Goiânia: tinha umas queimaduras nas pernas com ferro elétrico, uma coisa violenta. Havia um clima assim.

Conheci nessa época Maurício Goulart, que era um deputado federal da esquerda democrática, autor do grande livro que, do ponto de vista universitário, iria me marcar. Eu era amigo da filha dele, conversávamos na casa dele. Só mais tarde fui avaliar a importância da obra dele. Falo do livro A escravidão africana no Brasil, de 1949, que é o balanço do tráfico mais exato que foi feito na época. É um livro escrito por um não universitário, que fez essa pesquisa toda no Instituto Histórico, na Biblioteca Nacional. O Sérgio Buarque de Holanda² fez um prefácio elogioso na segunda edição do livro. 


\section{Você chegou a Brasília já com interesse na política?}

Um pouco. Mas lá havia esse clima em volta do Darcy, do Oscar Niemeyer, Evandro Lins e Silva, Hermes Lima, da geração de esquerda anterior à minha, que eu frequentava por causa da UnB e de amigos comuns. Era um ambiente muito exaltante. 0 maestro Cláudio Santoro organizava audições de gravações de concertos todas as tardes na UnB. Eu assisti a uma das primeiras exibições de Deus e o Diabo na Terra do Sol, apresentado por Paulo Emílio Salles Gomes, ${ }^{3}$ professor da UnB, no cineclube que ele dirigia. 0 momento político e cultural era às vezes tenso, mas vibrante. Tinha havido a Revolução Cubana, gente da UnB tinha ido a Cuba e voltava contando o que vira por lá.

\section{Vocês tinham alguma relação com as Ligas Camponesas?}

Sim, uma vez a gente foi a uma reunião em Goiás com um grupo ligado a elas. Fui com Paulo de Tarso Celestino, ${ }^{4}$ que também era da diretoria da Feub. 0 Paulo era moderado. Depois da reunião, ele disse: "Esse pessoal é muito radical, não aceita nem camponês de enxada nova. Assim não dá." Ele era contra toda radicalização. Mas foi acuado pela ditadura de fio a pavio, escondeu-se e em seguida participou da luta armada. Acabou assassinado debaixo de uma tortura atroz naquela sinistra casa de Petrópolis. Foi um pouco o que poderia ter ocorrido com vários de nós e o que aconteceu com Honestino Guimarães, nosso sucessor na Feub. Outros não foram mortos, mas foram torturados, presos, tiveram que se esconder, e suas vidas sofreram graves transtornos. Nas ditaduras, na América Latina ou no resto do mundo, você nem sempre escolhe a forma de fazer oposição. As circunstâncias e a própria repressão empurram às vezes parte dos oposicionistas para a clandestinidade e a luta armada. Quando vejo gente desinformada ou de má-fé dizer que Dilma "escolheu" a luta armada na sua juventude, acho um absurdo. Por que é que só teve luta armada no Brasil durante a ditadura, e não no regime constitucional, ao contrário do que aconteceu noutros países latino-americanos ou europeus? Por causa da ditadura, foi a ditadura que perseguiu uma parte dos oposicionistas e os empurrou para a luta armada.

\section{Em função desse clima de 1964, você foi preparando a sua saída...}

Sim, eu pedi uma bolsa na França. Deram para mim, para o José Almino de Alencar ${ }^{5}$ e para o Tito Ryff. ${ }^{6}$ Acabei tendo seis anos de bolsa do governo francês, para fazer a Sciences Po e o doutorado em História, em Paris. 


\section{Como foi radicar-se na França?}

Bom, eu já sabia falar francês. Isso facilitou as coisas. Havia o Institut d'Études Politiques, a Sciences Po, em Paris, mas também em Bordeaux, Grenoble e Aix-en-Provence. Fiquei amigo de um casal de estudantes franceses e eles me disseram: "Com o dinheiro dessa sua bolsa, aqui em Paris, você não vai longe; agora, em Aix-en-Provence, você vira um rei; com um Solex - uma bicicleta motorizada -, um carnê de tíquetes do restaurante universitário e a sua bolsa, você é dono da cidade." [risos] Eles sabiam também que eu queria sobretudo estudar História e me disseram que Aix tinha a melhor Faculdade de História da França. Então foi para lá que eu fui.

\section{Em Aix, você manteve seus contatos políticos?}

Em Aix eu fiz outro tipo de contato político. Pela primeira vez vi uma extrema direita estudantil organizada, assumida, agressiva, indo para cima dos estudantes de esquerda com cassetete. Era o movimento Occident, com estudantes anti-gaullistas e anticomunistas egressos das facções ultracolonialistas da Argélia, e a Action Française, monarquista. Tudo isso num ambiente marcado pela presença de ex-colonos franceses que haviam sido obrigados a abandonar a Argélia em 1962, numerosos em Aix e Marselha. Havia um ressentimento enorme com a descolonização promovida por De Gaulle. Os monarquistas da Action Française tinham um argumento atraente para o regionalismo provençal, occitano, porque defendiam uma maior descentralização dos poderes na França. Muitos deles falavam correntemente provençal. Depois de maio 68, parte deles virou maoísta, porque o maoísmo valorizava a cultura camponesa, pré-industrial e reforçava suas convicções regionalistas. Os estudantes da Córsega, que vinham muito para as faculdades de Marselha e Aix, também voltaram para sua ilha com essa cultura maoísta que, no caso deles, desembocou no movimento independentista corso. Quando comecei a dar aulas em Rouen, em meados dos anos 70, vi que havia essa mesma mistura de ultra-esquerdismo e regionalismo entre os estudantes bretões.

Havia outras coisas novas para mim em Aix. Fui a umas reuniões do Partido Comunista Internacional em Marselha. Não são trotskistas, são seguidores de Amadeo Bordiga, ${ }^{7}$ marxista italiano. Havia militantes antifascistas italianos e franceses, gente que havia combatido nas Brigadas Internacionais na Espanha e na Resistência na França. Eles eram antimilitaristas e anticolonialistas, mas diziam que o Ho Chi Minh ${ }^{8}$ o tema do momento era a Guerra do Vietnã - era defensor da burguesia vietnamita e que a guerra no Vietnã era uma luta entre 
burguesias nacionais, que não havia solução por aí [risos]... Mas eles tinham uma sólida cultura anti-estalinista e aprendi bastante com eles.

\section{Conte um pouco mais da sua formação acadêmica.}

Eu era obrigado a fazer o curso da Sciences Po, porque a minha bolsa era para Ciências Políticas. Todo mundo de terno, alunos e professores muito conservadores. Aliás, eu estou lendo agora o livro da Raphaëlle Bacqué sobre o Richard Descoings, ${ }^{9}$ que revolucionou a Sciences Po de Paris. Foi ele quem deu o doutorado honoris causa para o Lula. Descoings era um cara muito interessante. Tentou mudar a Sciences Po de Paris que, como em Aix, era uma instituição muito conservadora. Quando eu cheguei, em 1966, o ambiente era até reacionário, como disse antes, com monarquistas e ultracolonialistas fazendo discursos. Mas eu queria fazer História, para poder entender o presente. E, no caso do Brasil, as derrotas do presente, já que a ditadura, ao contrário do que nós pensávamos logo após o golpe, se instalava para ficar muito tempo no poder. Fiz então uma parte do diploma de História, que na época era ensinada junto com Geografia, paralelamente ao diploma de Sciences Po.

\section{E a sociologia? Porque para essa geração dos anos 1960 a sociologia tinha um peso no Brasil.}

Ah, é. José Almino foi fazer sociologia em Nanterre, era o momento glorioso da sociologia, com Raymond Aron, Edgar Morin, Touraine e em seguida Bourdieu. Mas quem dominava mesmo as Ciências Sociais e o Direito era a História. Foi o pico da influência dos Annales, ${ }^{10}$ e História era a ciência humana central na França. Havia muito interesse na América Latina. Porque a França tinha se dado mal na descolonização na África e recentrava sua diplomacia mundial privilegiando a América Latina, que desde Auguste Comte aparecia com uma área natural de influência francesa.

\section{Quando você chegou na França o estruturalismo tinha um peso, não?}

Ainda estava começando e nunca influenciou muito a História. Eu queria estudar História e lá estavam o Georges Duby, o Michel Vovelle, o Maurice Agulhon, o Paul Veyne. ${ }^{11}$ Havia um ambiente favorável porque os professores viviam próximos dos estudantes. 0 Brasil suscitava simpatia. 0 país tinha ganho notoriedade por causa da construção de Brasília, do crescimento industrial na época de JK e pelas vitórias da Copa do Mundo em 1958 e 1962. A 
cultura occitana também é próxima da gente. 0 provençal é uma língua que soa mais próximo do português que o francês ou o espanhol. Então eu me entranhei ali, era convidado para a casa de professores e amigos da universidade, assisti a missas em cidadezinhas em que 0 padre fazia o sermão em provençal... Aix era uma cidade pequena mas cosmopolita, e logo ao lado ficam Marselha, o Mediterrâneo. Os Alpes também ficam perto.

\section{E como era o clima intelectual na Universidade de Aix-en-Provence?}

A descentralização universitária no pós-guerra fez com que começasse a ressurgir a história regional nas universidades. Os pesquisadores ensinavam e moravam ali, o arquivo ficava na região. As teses de Agulhon e de Vovelle eram sobre a Provence moderna. Le Roy Ladurie, que ensinava em Montpellier, fez sua tese sobre os camponeses da região. Duby nos levava para visitar as três abadias medievais cistercianas da Provença. Houve também a descentralização dos arquivos na França, e os arquivos das ex-colônias foram para Aix-en-Provence. A gente chegava no arquivo e lá estavam caixas de documentos vindos da Argélia, do Senegal, do Congo Brazzaville, do Gabão. Havia esse ambiente em que a África estava bastante presente. Fui assistente de pesquisa num Centro de Estudos do Oceano Índico, onde redigia fichas sobre Moçambique. Ali e nos bares de Aix conheci bastante estudantes africanos, notadamente um historiador etíope brilhante, já doutor em Oxford, em seguida em Aix, e que depois foi assassinado pela ditadura de Mengistu. Outro, guineano, foi vítima de Sékou Touré. As crises das independências, das ditaduras africanas, e depois, das guerras civis, foram dramáticas. Guardei um grande respeito pela dignidade com que os estudantes africanos enfrentavam as adversidades de seus países e de seus povos.

\section{Aí veio maio de $68 .$.}

Foi uma coisa surpreendente. Porque ninguém entendeu o que estava acontecendo. Nem De Gaulle, nem o Partido Comunista Francês, nem a CIA, como se viu em documentos publicados mais tarde. Eu já estava lá havia dois anos. De repente, numa das manifestações em Marselha, começou-se a gritar contra o De Gaulle. Achei um disparate, porque De Gaulle era o herói dos latino-americanos e africanos, tinha restabelecido relações com a China, era contra a hegemonia americana e soviética, e aquilo tomou um rumo inesperado. Junto com outros estudantes, fomos para Paris em meados de maio. No final das contas, nos enganamos duas vezes. Primeiro a gente não entendeu o que estava acontecendo fora de Paris e das cidades universitárias. Alguns mais lúcidos comentavam: "Olha! Está cheio de bandeiras 
vermelhas aqui na Sorbonne." A estátua de Victor Hugo tinha uma bandeira vermelha, e a de Pasteur outra. [risos] Os mais céticos perguntavam: "Vocês acham que isso vai ficar aí? A França é assim?" Muitos de nós pensávamos que a esquerda estava muito forte depois das manifestações de maio, caracterizadas, é bom lembrar, pela maior greve operária num país industrializado no pós-guerra.

Mas a esquerda não estava tão forte assim. Tanto que De Gaulle dissolveu a Assembleia, convocou novas eleições e obteve uma maioria de direita mais ampla ainda nas Legislativas de junho de 1968. 0 segundo erro nosso foi, em seguida, achar que maio tinha acabado ali, com aquela vitória eleitoral da direita. Nos enganamos de novo. Primeiro, porque houve conquistas importantes para os trabalhadores. Teve aumento do salário mínimo, obrigatoriedade de delegado sindical nas fábricas, uma quarta semana de férias pagas anuais. Em seguida, e isso a gente só percebeu bem mais tarde, se viu que o movimento de maio de 68 provocou uma mudança cultural e social que revigorou a sociedade francesa.

\section{Conte agora da sua vida acadêmica pós-68.}

Eu me mudei para Paris, para fazer o doutorado com o Frédéric Mauro, que priorizava a história quantitativa, como o Pierre Chaunu, o Magalhães Godinho, o Pierre Vilar e um pouco o Ruggiero Romano, ${ }^{12}$ todos eles especialistas nos impérios ibéricos. O Ruggiero Romano disse isso, uma vez, num seminário: "Toda geração tem um livro dominante, que você quer fazer igual ou refutar. 0 da nossa geração é o War and Prices in Spain (1947), do Earl Hamilton." 13 Hamilton era o grande professor de história econômica de Chicago e estava renovando os estudos quantitativos sobre a crise do século XVII, sobre o impacto da prata espanhola vinda de Potosí, na atual Bolívia, na economia mundial.

Era a ponta da história quantitativa. Os discípulos do Braudel também se interessavam muito por Hamilton. Mas eu gostava mesmo era do Braudel. Li ainda na Faculdade em Aix a primeira edição de Civilização material e capitalismo, publicado em 1967, que mudou a minha cabeça. Braudel entrava no vivo, na vida material e nas mudanças ocorrendo dentro e fora da Europa moderna. Depois houve a edição ampliada do livro dele em três volumes, de 1979, que teve grande notoriedade. Com Mauro, trabalhei na tese e em grupo de pesquisas durante 15 anos. Junto com Chaunu, Mauro foi um dos primeiros doutorandos de Braudel. A tese dele foi publicada em 1960 num livro dedicado a Braudel, Le Portugal et l'Atlantique. Ele não pôs Brasil no título por fidelidade à ideia braudeliana de geo-história, na qual o que conta é o espaço, e não os países que ainda não existiam, como o Brasil. Podem dizer que é eurocêntrico, 
mas o fato é que eles estavam nesse projeto de integrar o mundo à economia dominante da época, à economia europeia.

Eu tomei um rumo um pouco diferente, porque havia lido a segunda edição de Brasil e África, de 1965, do José Honório Rodrigues, um livro pioneiro que é subestimado por boa parte dos autores brasileiros. O livro mostrava que o Brasil tinha um pulmão na África. Antes de 1808, Luanda era o segundo porto mais importante do comércio externo brasileiro. 0 primeiro era Lisboa. Depois de 1808, o primeiro lugar mudou de Lisboa para Liverpool, mas Luanda não mudou, continuou sendo o segundo porto mais importante das trocas externas brasileiras. Num artigo recente que apresentei no CPDOC, The Ethiopic Ocean: history and historiography - 1600-1975, tentei mostrar como Braudel, Mauro e Chaunu passaram batido sobre as ligações entre o Brasil e a África, deixando de lado o comércio bilateral, cuja existência eles não ignoravam. Para mim, esse "esquecimento" deles ilustra o pensamento dominante da época, que desconsiderava a África negra.

\section{Como foi o início da sua carreira docente na França?}

Eu comecei na Universidade de Paris VIII em 1973. Roberto Schwarz ${ }^{14}$ já dava aula lá. Tinha uma matéria nova sobre a relação Brasil-Estados Unidos, Roberto estava fazendo a tese dele sobre Machado de Assis, achava que essa matéria se afastava do assunto dele e me indicou como chargé de cours. Eu ainda nem tinha doutorado. Depois fui lecteur e assistente associado na Universidade de Rouen. Mas continuei em Paris VIII-Vincennes, no bosque de Vincennes, que depois se mudou para Saint-Denis, e lá fiquei até voltar para o Brasil em 1986. Roberto Schwarz acompanhou e influenciou minha produção intelectual desde essa época, devo muito a ele.

\section{Quando você foi para Paris, para fazer o doutorado, já tinha clareza da temática?}

Ah, já. O Duby tinha me proposto estudar o Portugal medieval. Mas eu não queria estudar Idade Média. Eu queria estudar o Brasil. E para isso era preciso procurar o Mauro. Ele estava em Paris $\mathrm{X}$-Nanterre.

\section{E você se reintegrou à comunidade brasileira que você tinha conhecido logo no início.}

É. Mas a comunidade havia mudado, porque começou a chegar do Brasil o pessoal fugindo da repressão violenta, luta armada e tal. Aí foi difícil para eles. Porque aquela gente 
chegava e não estava preparada para, de uma hora para outra, virar estudante, assistir aos seminários e se enfiar nas bibliotecas. 0 caso mais dramático e conhecido é o do frei Tito. Ele chegou a Paris depois de um período de prisão e tortura bárbara em São Paulo. Acabou se suicidando. ${ }^{15}$ Houve dois outros casos assim.

Na École des Hautes Études en Sciences Sociales, a EHESS, Alain Touraine, Daniel Pécaut ${ }^{16}$ e outros professores montaram um sistema que dava um diploma em Ciências Sociais e acolhia exilados latino-americanos. Sobretudo depois do golpe no Chile (1973), que causou muita indignação na França. Mitterrand e a esquerda francesa se sentiam próximos do Allende, que contava ainda com a simpatia dos maçons franceses. Com a inscrição na EHESS, os exilados estudantes tinham o RG de estrangeiros garantido e retomavam o vínculo universitário. Mauro também recebeu muitos desses estudantes assim, da mesma forma que Celso Furtado. Esses professores foram fundamentais no novo rumo de vida dos jovens intelectuais exilados. Houve esse momento de debate de ideias sobre a América Latina e o que estava ocorrendo no Vietnã e na África. A Universidade de Paris é uma das únicas universidades de primeira linha que está dentro de uma grande capital, de um grande centro cosmopolita e cultural europeu e mundial.

\section{Como tem sido a evolução recente da cadeira que você ocupou na Sorbonne e dos estudos sobre o Atlântico Sul?}

O Mauro estabeleceu a área dos estudos do Atlântico Sul, mas na prática não teve sucessor. Ao mesmo tempo a União Europeia foi se ampliando e, com o fim da Guerra Fria, muitos pesquisadores se voltaram para o estudo da Europa Central e do Leste. Hoje há menos interesse pela América Latina e pelo Brasil do que nos anos do pós-guerra. Houve uma ameaça, quando eu substituí a Katia Mattoso ${ }^{17}$ em 2000 na cátedra que era de História do Brasil, de que ela virasse de História da América Latina inteira, ou talvez da Europa Central. Isto porque a cátedra da Europa Central foi fundida com a de História Militar durante a Guerra Fria. Então sempre houve esse suspense.

Da primeira vez, houve um esforço para manter a cátedra de História do Brasil. O Mauro participou do movimento, ao lado dos colegas da Sorbonne e da Katia, que também defendiam a cátedra. Com a Katia, a cátedra estudava o Brasil e em parte a América Latina. Eu dei a virada para estudar o Brasil no Atlântico Sul, incluindo a África ocidental e Moçambique, e sobretudo Angola, como também o Rio da Prata. Quem salvou a cátedra em 2014, quando me aposentei e Laura de Mello e Souza foi eleita, foram os colegas da Sorbonne favoráveis à sua continuidade e o Aloizio Mercadante, que era ministro da Educação. Ele foi bem recebido na Sorbonne porque muitos alunos do programa Ciência sem Fronteiras estavam indo para lá. Porém quando Laura 
se aposentar, pode haver de novo o mesmo risco de supressão da cátedra de História do Brasil. É preciso lembrar que o Brasil tem uma importância relativa para a França por causa da fronteira comum com a Guiana Francesa, que é a maior fronteira internacional francesa.

\section{Sobre História e Historiografia, suas teorias e métodos, que balanço você faz e que caminho vê para o futuro da História?}

Vale a pena observar que uma tendência historiográfica na França não excluía as outras. Isto é, o estruturalismo não tirou a importância da história econômica, a história das mentalités não acabou com a história econômica ou com a história quantitativa, ao contrário do que às vezes se acredita aqui. Eu comentei isso num artigo da revista do Cebrap que se chama "Que mentalidade é essa?" 18 No Brasil havia uma excelente base de historiografia econômica, atlântica e quantitativa, criada pela Alice Canabrava, que foi a grande discípula do Braudel na USP. Ela estudou história atlântica e formou toda uma geração. Formou o Francisco Vidal Luna, formou o Flávio Saes, o Delfim Neto; e o Mauro deu apoio, organizou em 1972 um colóquio de história quantitativa do Brasil em Paris que foi uma grande virada também. Muitos pesquisadores da área eram mulheres, aliás. Além de Canabrava havia Bárbara Levy, Maria Yedda Linhares, Eulália Lobo, que fez aquele trabalho notável de história quantitativa do Rio de Janeiro, Kátia Mattoso, Cecília Westphalen.

\section{Todas mulheres.}

Mulheres. É interessante. Maxine Berg, uma historiadora da Universidade de Warwick, escreveu um ensaio sobre a contribuição das historiadoras econômicas britânicas à disciplina. Penso que o assunto também poderia ser estudado no Brasil. Digo isso porque já ouvi colegas falando que "a feminização da profissão é que levou ao domínio da história cultural". Não é por aí. Havia uma temática de história econômica muito sólida, com grandes professoras e pesquisadoras. A temática não se consolidou porque veio a voga da história cultural, que tem trabalhos importantes, mas também trabalhos onde se ignoram as relações de força ou o contexto geral.

Com a micro-história, há pesquisadores que seguem os traços de um só indivíduo, como se ele fosse o depositário do saber de toda uma região ou de toda uma época, e o estudo de caso vira o estudo do mundo. Hoje há pesquisadores que não sabem elaborar ou ler um gráfico, analisar dados quantitativos. Na França e nos outros países isso não acontece. Duby e Le Roy Ladurie, nomeados quase na mesma época no Collège de France, possuíam uma sólida formação em história econômica. Na mesma época Roland Barthes e Michel Foucault entraram no Collège, e o trabalho deles dialogava com o de Duby e de Le Roy Ladurie. 


\section{No Collège?}

No Collège. Na aula inaugural do Foucault estava o tout Paris... [riso]. Na aula do Barthes havia o tchan intelectual e mais o tchan elegante, moças e senhoras de chapéu... Na aula inaugural do Duby tinha pouca gente na moda, mas penso que ele gostou desse contraste. Ele escreveu livros de história da arte, de história agrária e econômica, história das mentalidades, e também reinventou a história das batalhas e a biografia histórica, como em o Guillaume le Maréchal. ${ }^{19}$ Por isso ele achava que os velhos mestres dos Annales já faziam o que Jacques Le Goff ${ }^{20}$ depois intitulou la nouvelle histoire. ${ }^{21} \mathrm{~A}$ temática da biografia inserida nas transformações da época do biografado já estava no Martin Luther do Lucien Febvre..22 A história das mentalidades já estava presente no Les Rois Thaumaturges de Marc Bloch. ${ }^{23}$ Quanto a Braudel, que era da geração anterior do Collège, ele criticou pesado a virada culturalista dos seus sucessores nos Annales, que acabaram tirando em 1994 a palavra "Economia" do título da revista: "Se os meus sucessores [na direção dos Annales] preferem estudar as mentalidades negligenciando a vida econômica, pior para eles!", disse ele num debate publicado na Review, revista dirigida por Immanuel Wallerstein, em 1978. Nesse debate historiográfico, eu sigo sem hesitar o ensinamento de Duby, Le Roy Ladurie e Braudel.

\section{Queríamos falar um pouco sobre o papel da geografia. A impressão que fica é de que a geografia é um argumento central no seu livro $O$ trato dos viventes. Você tem uma formação, também, em geografia, e isso parece ser um dos vínculos que ligam você a Braudel. Você se sente ligado a esse materialismo geográfico do Braudel? Qual é o papel da geografia na sua obra?}

Bom. Isso é próprio do ensino na França, da geração dos Annales a que me referi, e em particular do Braudel, que era considerado um "geo-historiador". Quando eu estava na graduação, como disse, fiz História e Geografia juntas. A tese do Duby, sobre a abadia de Cluny, perto de Macon, onde ele cresceu, é muito ligada à geografia, como também seu livro intitulado L'économie rurale et la vie des campagnes dans l'Occident medieval, de 1962. Mauro também insistia muito no enfoque geográfico. Embora, como eu disse, Braudel e sua geração dos Annales, no que concerne aos estudos africanos, sejam decepcionantes. Os mapas do Mauro sobre o Atlântico Sul, que o Chaunu desenvolveu, são mapas muito úteis para entender as rotas entre a Europa e a América, porque mostram as distâncias em tempo real, conforme as estações do ano. No inverno, era mais longe ir do Brasil para a Holanda, para Portugal, durante a guerra holandesa, e no verão era muito mais perto, por causa do sistema 
de ventos e correntes. Mas nesses mapas não havia as ligações do Brasil e do Rio da Prata com Luanda e outros portos africanos. Na configuração do espaço histórico deles, a África ficava meio de fora. As relações bilaterais, magistralmente estudadas mais tarde por Pierre Verger$^{24}$ não foram levadas em conta.

\section{O Fluxo e refluxo. ${ }^{25}$}

Fluxo e refluxo do tráfico de escravos entre o Golfo do Benin e a Bahia de Todos os Santos, de 1968. Braudel dirigiu a tese e publicou esse livro do Verger. Mas ele não cita o Verger em Civilisation matérielle. Mais curioso ainda, ele diz que o esquema geral do tráfico negreiro era o comércio triangular. Quando ele aborda a questão do tráfico, cita essencialmente o livro do Philip Curtin ${ }^{26}$ sobre a Senegambia, junta lá um outro material, mas não tem Boxer ${ }^{27}$ nem Verger... O livro do Curtin, sobre o balanço do tráfico negreiro, saído em 1968, já era bem conhecido. Mas Braudel também não o utilizou.

\section{Quando você começou a pesquisa documental para sua tese?}

Em 1973. Pesquisei os arquivos franceses, no Quai d'Orsay, nos Archives Nationales, lendo a correspondência consular e diplomática com o Brasil depois da Independência. Houve um verão em que eu fiquei sozinho em Paris, e estava um caloraço. A Bibliothèque Nationale era ainda na rue Richelieu, era um lugar fresco e agradável. E eu li toda a coleção da Revista do Instituto Histórico, que estava numa das prateleiras de acesso livre. Pegava dois, três volumes, e pau na máquina. Li a coleção toda, passei o verão e os meses seguintes lendo e anotando. Depois, o Jornal do Commércio de meados do século XIX. Li também o Almanak Laemmert, começando pelos exemplares que havia na BN, porque para ler o resto era preciso ir até a British Library. Hoje, você vai nos sites e está tudo lá, a coleção completa digitalizada.

Entre outras coisas, eu percebi que havia um problema, no século XIX, com o tráfico. Um problema que Caio Prado Jr. ${ }^{28}$ e Stanley Stein ${ }^{29}$ já tinham observado: como o Império havia resistido tanto tempo às pressões inglesas para manter o tráfico de africanos até 1850 ? Achei que devia estudar o assunto do final para o começo, seguindo o "método regressivo" aconselhado por Marc Bloch, partindo de 1850 para os períodos anteriores. Meu orientador, Mauro, tinha me proposto estudar o Barão de Mauá, a ruptura do tráfico, a reciclagem de capitais negreiros, que era história econômica. Eu pensei: não, bom é ir para trás. Propus a mudança do tema e ele topou. 


\section{0 que mudou quanto ao acesso à fonte e à construção dos objetos de estudo?}

Quando eu escrevi $O$ trato dos viventes, só havia sete mil viagens negreiras no Database. Agora o TSTD incluiu dados de 35 mil viagens. Mudou muita coisa. E a mudança vai mais no sentido do que eu estava achando antes. Há mais coisa de Angola, com um comércio muito mais bilateral com o Brasil do que se pensava. Também ficou mais claro o impacto dos Asientos portugueses - contratos de fornecimento de escravos para a América espanhola entre 1595 e 1640 - na construção das redes sul-atlânticas. No meio tempo, boa parte da documentação de Angola, e praticamente toda a documentação do Brasil colonial, ficou disponível digitalizada. A hemeroteca online da Biblioteca Nacional do Rio de Janeiro é também um excelente instrumento de trabalho.

Para ser mais preciso, o TSTD mostra que $95 \%$ dos navios que trouxeram africanos para o Brasil entre 1550 e 1850 saíram de portos brasileiros. Estamos falando, então, de uma rede no Atlântico Sul que é o elemento essencial, transcontinental, de formação do Brasil. Como o Atlântico Norte, o Caribe ou o Oceano Índico, o Atlântico Sul é uma área em si, um espaço cultural e econômico distinto. Esse espaço, que incorpora o Brasil, o Rio da Prata - que desde o final do século XVI exportou prata via Buenos Aires, Rio de Janeiro e Luanda para Sevilha e Lisboa, e de lá para a China -, formava um dos eixos da economia-mundo. Depois, na primeira metade do século XIX, Moçambique também foi incorporado às redes sul-atlânticas pelos negreiros do Rio de Janeiro.

\section{No debate teórico-metodológico, onde esteve e onde está a História Econômica?}

A História Econômica perdeu espaço, tanto no Brasil como na Europa e nos Estados Unidos. 0 símbolo mais evidente foi a supressão da palavra "Economia" do título dos Annales, como mencionei antes. Porém sou menos pessimista hoje em dia, vendo a evolução dos especialistas da nova geração. 0 sucesso mundial do livro de Thomas Piketty, ${ }_{1}^{30}$ que tem seções onde a influência da École des Annales é nítida e assumida, mostrou de novo as vantagens de inserir o estudo da economia contemporânea na longue durée braudeliana. Os ex-colegas dele no MIT, Daron Acemoglu, Dora Costa e James A. Robinson, ${ }^{31}$ também ajudam a renovar o prestígio da história econômica. No Brasil, Ângelo A. Carrara, Alexandre Saes e Leonardo Weller, ${ }^{32}$ entre outros, são um bom exemplo dos pesquisadores da nova geração que fazem história econômica a partir da pesquisa de fontes primárias. Com exceção do Carrara, formado em História, todos os pesquisadores que citei, tanto estrangeiros como brasileiros, são economistas de formação. Por que os historiadores se desinteressaram da história econômica? Está 
aí um assunto sobre o qual os conselhos científicos das revistas, os departamentos de História e as agências de financiamento de pesquisa deveriam debater. Como dizia Braudel, sem o estudo da economia, os historiadores perdem um terreno comum que facilita grandemente seu diálogo com muitas outras disciplinas.

Há outras lacunas que ilustram o isolamento dos historiadores brasileiros e limitam sua colaboração com as outras disciplinas. Por exemplo, são raros os pesquisadores sinólogos, sabendo-se que a China, grande potência, é o primeiro parceiro comercial do Brasil desde 2009. Sabendo-se ainda que há volumosa documentação em português gerada em Macau sobre a China. Há obviamente muito interesse pela China no Brasil, mas os historiadores e os cientistas políticos têm pouco a dizer sobre a história e a política chinesa. Da mesma forma, a desconsideração da história marítima, praticamente ausente do ensino de História, ou do direito marítimo, pouco ensinado nas faculdades de Direito do país, ilustra o desconhecimento do papel econômico e geopolítico dos oceanos. Como já disse, o Brasil possui a maior costa atlântica do mundo. Além disso, 90\% do comércio mundial utilizam as rotas marítimas e 99\% da Internet passam pelos cabos submarinos, muitos dos quais imersos ao longo do litoral brasileiro.

\section{E a que você reputa isso? A uma certa especialização das disciplinas?}

0 desinteresse pela história econômica foi em parte causado pelos próprios pesquisadores da minha geração e pelos nossos professores. Começou-se a tirar conclusões e a fazer modelos econômicos de períodos e de problemas históricos com dados e séries estatísticas de confiabilidade duvidosa, sem sequenciamento, para dar lugar àquelas conclusões, àquela modelização. Quem estiver interessado no assunto deve ler a polêmica entre Michel Morineau ${ }^{33}$ e Le Roy Ladurie nos Annales. Paralelamente, houve a voga da micro-história, impulsionada pelo impacto de 0 queijo e os vermes de Carlo Ginzburg, ${ }^{34}$ que emplacou em toda a parte, inclusive nos Annales. Hoje, a micro-história, os estudos de caso e a abordagem culturalista dominam as pesquisas históricas. Quero contar algo que aconteceu comigo. Em 2006, meu artigo sobre o Atlântico Sul, no dossiê sobre o Brasil que organizei nos Annales, tinha como título inicial "O Brasil de 1550 a 1850: um ensaio de macro-história". Um membro da redação da revista me disse que o título podia ser interpretado como um ataque à micro-história e me pediu para mudar. Eu achei que não era o caso de encrencar e, por sugestão de Serge Gruzinski, dei um título que achei bem melhor: "A vertente brasileira do Atlântico Sul: 1500-1850". 


\section{No Trato dos Viventes, o econômico é uma determinação fundamental. Mas o indivíduo também é uma unidade de análise.}

É. Mas isso vem do Braudel. Ao contrário do que pensam alguns prosélitos da microhistória, é possível e é muito interessante combinar macro-história e micro-história. 0 Braudel faz isso o tempo todo, Serge Gruzinski também.

\section{Mas o que Sanjay Subrahmanyan, pelo menos, comenta sobre a obra de Braudel é que é uma visão do Mediterrâneo a partir de fontes e de um indivíduo do Norte, cristão, e que era preciso dar um passo a mais para entender o outro. Eu não sei se esse passo a mais só foi possível dar com a evolução do acesso a fontes e de novas metodologias, ou se já havia essa consciência nos Annales.}

Veja bem. 0 desafio é elaborar uma história global. Desde o começo existiram opiniões sobre tal ou tal região negligenciada, sobre a documentação que Braudel não viu e sobre a pouca atenção que ele dedica às religiões ou à arte. Obviamente, ele sabia disso. No entanto, com as fontes disponíveis e o material da época - o xerox "portátil" que eles carregavam pelos arquivos europeus afora parecia um piano sem pés -, ele elaborou uma interpretação global do Mediterrâneo. Em seguida, ele transpôs essa abordagem para a esfera mundial nos três volumes de Civilização material. São obras que se sustentam perfeitamente até hoje. 0 fato é que Sanjay deixou de lado a abordagem mais ampla e também faz agora estudos de caso, e que ninguém conseguiu igualar a perspectiva global de Braudel.

\section{Quando você foi a Angola pela primeira vez?}

Foi em 2003, logo depois da primeira visita de Lula ao país. Entre outras coisas, eu estava atrás de textos inéditos de Cadornega, que não achei e que provavelmente se perderam nos tumultos da independência e da guerra civil angolana. Cadornega é o autor da História geral das guerras angolanas, em 1681. É a primeira história de Angola, de um enclave colonial europeu na África, escrita a partir do ponto de vista dos colonos que estavam ali havia três gerações, não de um viajante. É uma obra sem igual na Europa. Em 2003 a guerra civil havia terminado, e populações isoladas durante anos em zonas de combate começaram a vir para Luanda e Benguela para procurar familiares etc. Vi órfãos e adolescentes trazidos para Luanda por uma ONG, com olhar perdido, assustados. Imaginei então como devia ser Luanda, o maior porto negreiro da África, quando ali chegavam continuamente do interior, às vezes de lugares 
situados a um ano de caminhada, grupos de escravizados para serem embarcados à força, a pauladas, para a América, para o Brasil, onde eles acreditavam que seriam devorados pelos colonos porque ninguém voltava dessa viagem.

\section{Você insiste na necessidade de se considerar que o Brasil, no início, era somente uma série de feitorias e de pequenos enclaves coloniais.}

A historiografia dominante ensina que existe, desde o século XVI, uma colônia portuguesa toda desenhada na América do Sul. Isso está na maioria dos livros, desde os manuais escolares até as grandes obras escritas sobre o Brasil por brasileiros e estrangeiros. Autores e revisores editoriais têm o hábito de escrever colônia com C maiúsculo, dando um sentido quase ontológico, premonitório da nação, aos enclaves e feitorias portuguesas seiscentistas e setecentistas. No meu livro 0 trato dos viventes, está escrito assim. Mas vou mudar isso na edição atualizada que acabei de preparar. De fato, a ideia de que haveria "Colônia" nos séculos XVI e XVII induz à premonição da nação, da nacionalidade e do futuro Estado brasileiro, gerando um flagrante anacronismo histórico: tudo se passa como se o futuro do Brasil inteiro já estivesse programado na Carta de Pero Vaz de Caminha. Ora, nós sabemos que nem toda feitoria vira colônia e que nem toda colônia vira nação. Macau, fundada em 1557, três anos depois de São Paulo, continuou feitoria até o fim, até ser engolida pela China em 1999. A Martinica, colônia francesa até 1946, foi em seguida plenamente integrada à França.

Ao saltar a etapa das feitorias perde-se uma forma essencial da expansão do capitalismo mercantil. De onde vem essa lacuna? Vem de um livro de 1874 do economista francês Paul Leroy-Beaulieu, ${ }^{35}$ que foi muito divulgado aqui, citado em toda parte, como se pode constatar na hemeroteca da Biblioteca Nacional. Leroy-Beaulieu era titular da cátedra de Economia Política do Collège de France e muito considerado na Europa. Ele teve muita influência no Brasil.

\section{Como assim?}

As formulações dele passaram para o Roberto Simonsen, para o Caio Prado, para Celso Furtado, e se estabeleceram como padrão de modelos coloniais estudados nas universidades brasileiras. Leroy-Beaulieu escreveu que há dois tipos de colônia, colônia de exploração e colônia de povoamento. Todo mundo estudou e ainda estuda isso no Brasil. Porém ele analisava explicitamente a segunda expansão europeia, estadunidense e russa 
(no Cáucaso), que estava em curso quando ele publicou seu livro. Leroy-Beaulieu desconsidera as feitorias e os entrepostos, enfiando tudo na categoria de colônia de exploração, porque na época dele o domínio territorial era mais importante do que nos séculos XVI e XVII, quando o que contava era o acesso ou o controle de determinada área mercantil através das feitorias. As feitorias são um elemento chave para o capitalismo financeiro de hoje como eram para o capitalismo mercantil de ontem. De ontem e de hoje, sim senhor. As Ilhas Cayman são uma feitoria caribenha cujo papel é fundamental para as grandes fortunas, bancos e multinacionais do século XXI.

Oliveira Martins, ${ }^{36}$ que leu Leroy-Beaulieu mas conhecia bem o papel dos entrepostos comerciais na expansão europeia, corrigiu o economista francês. Em O Brasil e as colônias portuguesas, livro de 1880 obrigatório para os historiadores brasileiros e portugueses, ele define três modelos de expansão colonial: as feitorias, que ele também chama de "colônias comerciais", as colônias exportadoras e as colônias de povoamento. Braudel observou que a distinção entre colônia de povoamento e de exploração não fazia sentido porque os dois processos coloniais se misturam e se completam. Isso é nítido nas Treze Colônias americanas.

Em alguns lugares, as feitorias e enclaves mercantis têm um impacto decisivo no hinterland, como é caso na Amazônia e mais ainda em Angola. A conexão da economia atlântica com a economia continental africana, através das feitorias litorâneas portuguesas, teve efeitos devastadores nas sociedades nativas da região. Por isso, Jan Vansina ${ }^{37}$ escreve que desde 0 final do século XVII Angola se apresenta como a primeira colônia europeia - colônia mesmo para valer - na África. Noutros lugares, a feitoria fica isolada, como em Macau, que já citei, ou em Dejima, na baia de Nagasaki. Ali, o xogunato construiu uma ilha artificial, isolou os holandeses lá dentro e disse "é só para fazer comércio, não saiam daí, viu!". O lugar hoje em dia é um museu. Está no Youtube. Eu mostro para os meus estudantes e explico: "os holandeses fizeram um comércio importante com o Japão durante dois séculos, trancados ali". Colonizar o Japão é algo que nem passou pela cabeça deles. Como também não passou pela cabeça dos portugueses colonizar a China a partir de Macau. Só os jesuítas tiveram essa ilusão, mas do jeito deles, como "conquista espiritual".

Na América portuguesa o processo foi diferente, o que explica em boa parte a sua singularidade: trata-se do único agregado colonial europeu na América que não se fragmentou na independência. De fato, a junção da exploração do ouro e da importação maciça de africanos permitiu que Minas Gerais se tornasse o centro dinâmico da economia brasileira no século XVIII, como Celso Furtado mostrou. Antônio Cândido mostrou também que este processo engendrou a literatura brasileira. Os dois escreveram isso em 
1959 nos seus respectivos livros, ambos intitulados Formação: da economia brasileira e da literatura brasileira.

É isso que transforma o Brasil numa colônia: a soma da dinâmica do ouro com a dinâmica negreira sul-atlântica. Aí sim, quem quiser pode tascar o "C" maiúsculo. Não é à toa que é também no início do século XVIII que o designativo "brasileiro" vira substantivo de naturalidade. A propósito, note-se que o Brasil e a Costa do Marfim são os únicos países do mundo que têm nome de mercadoria, de commodity. E o Brasil é o único país do mundo no qual o substantivo de naturalidade deriva de uma função mercantil, no caso, comerciante de pau-brasil. Porque o sufixo eiro, nas línguas neolatinas, em francês, em italiano, em espanhol, em português, indica função, não naturalidade. Não é brasiliense, ou brasiliano, como canadense ou americano, é brasileiro, como pedreiro, carpinteiro, padeiro.

Para avaliar as transformações do século XVIII, quando emergem o mercado interno e os contextos econômicos e culturais protonacionais, é preciso entender como os enclaves comerciais e produtivos do litoral se juntaram ao centro mineiro. É claro que o ouro teve um papel fundamental, mas o Atlântico Sul também. Graças ao fluxo maciço de africanos que chega aos portos brasileiros, são mantidos os enclaves açucareiros do litoral, enquanto brota no interior uma economia aurífera e toda a zona subsidiária. Na realidade, como escrevi alhures, todos esses ciclos, do açúcar, do ouro do café, são subciclos dependentes do longo ciclo do tráfico negreiro, de 1550 a 1850.

\section{Porque o domínio territorial não era fundamental.}

0 território em si não tinha importância, ou melhor, a vantagem econômica de possuir vastos territórios ultramarinos não era evidente até o século XVIII. O que contava era a feitoria, o comércio, mesmo realizado com mercadorias produzidas em enclaves coloniais, como nas zonas açucareiras do litoral antilhano e sul-americano. De uma maneira geral, isso vale na América, África e Ásia. 0 setor mineiro hispano-americano, explorado pelos colonos e pelo trabalho compulsório indígena, levou a uma interiorização do domínio espanhol. Mas no golfo de Guiné, onde o ouro foi explorado diretamente pelos povos Akã, os luso-brasileiros, os portugueses e os outros europeus permaneceram incrustados nas feitorias do litoral. 0 quadro muda na América portuguesa no século XVIII, pelas razões que citei acima e por causa da geopolítica ibérica. Houve o acordo mundial de fronteiras entre a Espanha e Portugal, corrigindo o Tratado de Tordesilhas com o Tratado de Madri em 1750. Esse acordo, cuja implementação conhece reviravoltas, tem três etapas. Portugal larga as regiões asiáticas onde contestava os direitos de posse espanhóis em troca de Minas Gerais, Goiás e Mato Grosso, o polígono 
mineiro, cuja posse não the era assegurada até então. Em seguida, Lisboa troca a feitoria de Colônia do Sacramento pelo território do Rio Grande do Sul, base da pecuária que fornecia a logística mineira com mulas e gado de corte.

0 autocentrismo dos muitos autores brasileiros acha que Minas Gerais está na base do Tratado de Madri. Não é bem assim, o tratado é planetário. Foi o abandono das pretensões territoriais portuguesas nas Filipinas, registrado logo no artigo $2^{\circ}$ do Tratado, que destravou o contencioso de fronteiras na América portuguesa. De uma maneira mais geral, a vantagem econômica dos territórios só ganha importância na segunda metade do século XIX, depois da unificação da economia americana no final da Guerra de Secessão e do barateamento do transporte trazido pelos navios a vapor e pelas ferrovias. Aí sim, fica interessante para os europeus ter grandes territórios ultramarinos com reservas de matérias- primas e terras aráveis. É a segunda expansão europeia, acoplada na Segunda Revolução Industrial, no excedente demográfico europeu, no melhor controle das doenças tropicais, na extensão das redes de telégrafo ultramarinas, no moderno sistema bancário, no transporte a vapor, na supremacia militar do Ocidente que não era patente na primeira expansão. A transformação das feitorias portugueses num espaço maior, levando à fusão do Estado do Maranhão com o Estado do Brasil, só ganha sentido quando se dá plena dimensão ao tráfico negreiro, ao Atlântico Sul.

\section{E depois da Independência?}

Sem entender que o Brasil tinha um pulmão em Angola não se compreende por que o Império insistiu tanto, e quase foi à breca em 1850, na sua obstinação em manter o tráfico frente ao poderio da Inglaterra e da Royal Navy. Bernardo Pereira de Vasconcelos, senador e conselheiro de Estado, um dos pais da pátria, achava que o Brasil acabava se o tráfico fosse extinto. Essa ligação orgânica das duas partes sul-atlânticas relativiza a ideia de territorialidade. A economia brasileira tinha uma dependência orgânica do acesso aos mercados negreiros africanos, de Angola, mas também da Senegâmbia, da Costa da Mina e de Moçambique. E isso é que é a diferença do Brasil, no século XIX.

\section{Ao mesmo tempo, como você propõe, são os interesses em torno da escravidão que explicam a nossa unidade nacional. É isso.}

0 que eu digo é o seguinte. Havia um equilíbrio perverso no qual a Coroa se equilibrava entre duas forças antagônicas: a Inglaterra, que queria acabar logo com o tráfico 
frente às oligarquias escravocratas, que queriam continuar a importar africanos. As regiões brasileiras eram todas negreiras, todas dependiam em maior ou menor grau da escravidão para se manter. Há uma ata do Conselho de Estado de 1846 muito interessante. 0 Conselho de Estado analisa a rede de tratados que a Inglaterra construíra para isolar diplomaticamente o Brasil, proibindo o tráfico negreiro na Bolívia, na Argentina, no Uruguai, no Peru, no Texas, que era independente na altura, na Europa inteira. Havia a rede diplomática britânica e, por trás, a Royal Navy. Quem saísse do Império brasileiro reivindicando a independência regional na Bahia, em Pernambuco, imediatamente esbarrava nessa rede. Reconhecia-se quem tinha escravidão, mas fazer tráfico não era aceito. E nas províncias brasileiras, quem foi para o pau mais pesado? As zonas onde o escravismo não era dominante: a Balaiada, no Maranhão e no Piauí, e a Farroupilha, no Rio Grande do Sul. Zonas ganadeiras. Com rebeldes dispondo de grandes contingentes de cavalaria. Só o poder central monárquico do Rio de Janeiro, com suas redes diplomáticas e dinásticas para postergar as pressões inglesas e manter o tráfico até 1850. Foi o único país independente que conseguiu isso.

\section{No subtítulo do seu Trato dos viventes aparece a categoria "formação" - "Formação do Brasil no Atlântico sul" -, que é uma categoria que remete à produção de alguns grandes intérpretes do Brasil. Isso quer dizer que o século XVII é realmente o século decisivo?}

Você sabe, há um ensaio sobre o assunto, escrito pelo Paulo e pela Otília Arantes ${ }^{38}$, Sentido da formação, e foi isso que me deu a ideia. Eu achei meio ousado, mas resolvi ir em frente depois que tive o aval do pessoal da pizza, que é a turma de São Paulo com que me reúno há muito tempo nos domingos, da qual Paulo e Otília, Roberto Schwarz, meu mestre, e outros, fazem parte.

\section{A palavra formação já estava na sua tese de doutorado, no subtítulo da tese?}

Não. O subtítulo da tese é "Pax Lusitana no Atlântico Sul". A tese cobre um período mais longo, vai até 1850. Mauro achou que, além dele e de Celso Furtado, que acabou só participando da pré-defesa porque foi nomeado ministro da Cultura e voltou para o Brasil, devia haver na banca dois africanistas, Jean Devisse e Claude Meillassoux ${ }^{39}$.

Logo em seguida eu voltei para o Brasil, em 1986, e li dois trabalhos que modificaram meu ponto de vista. Li o trabalho do Evaldo Cabral de Mello, de quem eu já conhecia Olinda restaurada, e percebi que tinha que integrar mais as análises dele. Li o trabalho do John 
Monteiro, ${ }^{40}$ e senti que tinha de resolver a questão da escravidão indígena em São Paulo, levantada por ele, com quem em seguida trabalhei no Cebrap. Aí resolvi fazer minha tese de livre docência sobre século XVII. E o Celso Furtado, com quem discuti muito a minha tese e a livre docência, reforçou: "Você tem que entender o século XVII melhor".

\section{Por quê?}

Porque a historiografia dominante é baseada num modelo calcado no Paul Hazard, ${ }^{41}$ na Inconfidência Mineira, situando a crise do sistema colonial no século XVIII. Não, o problema já vinha do XVII, quando Portugal estava sob domínio espanhol e perdeu boa parte da Ásia, tendo assim que se associar às oligarquias dos colonos do Brasil para gerir o Atlântico Sul, para reconquistar Angola e manter sua presença na Costa da Mina. Isso se transformou numa cogestão portuguesa e luso-brasileira do Atlântico Sul, que vai além da abertura dos portos e da Independência. Em resumo, para entender o século XIX, o Império, é preciso estudar o século XVII, as guerras holandesas. A irrupção de potências rivais no Atlântico Sul, os holandeses no século XVII e os ingleses no século XIX, causa crises que põem a nu a ligação orgânica entre o Brasil e a África.

Dessa constatação decorre algo que abre um debate de história para valer, que é a mudança da periodização. Quando você muda a periodização, você mexe com tudo, num certo sentido. Quando o François Furet ${ }^{42}$ questionou a periodização dominante sobre a Revolução Francesa, a tríplice ruptura gerada pelo 14 de Julho, que teria suscitado uma revolução cultural, econômica e política, que era a tese da Sorbonne - do Soboul ${ }^{43}$-, o bicho pegou. Essa foi a grande briga da periodização motivada pela proximidade do bicentenário da Revolução Francesa em 1989. No Brasil, o debate acadêmico se dá em torno da dimensão das rupturas ocorridas em 1808 e 1822. Se você acha, como eu, que a ruptura de 1850 é crucial, com o final do tráfico marcando a fratura da matriz espacial colonial que unia o Brasil à África, você mexe com a periodização toda. Para a frente e para trás. A montante, a Inconfidência Mineira passa a ser um episódio secundário, como pensava aliás Capistrano de Abreu. A jusante, a Lei do Ventre Livre perde a centralidade na crise que leva à Abolição. Porque a crise do escravismo passa então a ter seu epicentro em 1850, no final do tráfico e no debate da Lei de Terras.

\section{Como o Atlântico Sul se integra à América Latina hoje em dia?}

Aqui é preciso marcar o contraste entre os dois espaços geopolíticos. O Brasil só se sente integrado no espaço latino-americano, na ideia de América Latina, depois da proclamação 
da República. É nessa época, em 1905, que é publicado o livro do Manoel Bonfim, ${ }^{44}$ A América Latina, males de origem. Antes disso, os pensadores latino-americanos hispanófonos rejeitavam igualmente o Brasil, uma monarquia, e o Haiti, país negro. A identidade latino-americana do Brasil se desenvolveu entre os juristas e os teóricos do direito pan-americano. A realização do I Congresso Jurídico Americano no Rio de Janeiro, em 1900, durante as comemorações do IV centenário do descobrimento do Brasil, marcou data. Depois da Segunda Guerra e da fundação da Cepal, ${ }^{45}$ quando os países latino-americanos pesavam na ONU, na ausência dos países africanos e asiáticos que ainda eram colônias, a identidade latino-americana brasileira atingiu seu ápice. Foi nesse contexto que os cepalinos do Brasil, Celso Furtado, FHC, Maria da Conceição Tavares, Chico Oliveira e outros, prepararam sua obra intelectual e suas atividades públicas. Durante a ditadura, houve a experiência cubana e sobretudo o exílio no Chile de Allende, que também marcou intelectuais e militantes importantes nos governos FHC e Lula, como Weffort, José Serra, Plínio de Arruda Sampaio e Marco Aurélio Garcia. Darcy Ribeiro, que andou pela Argentina, Peru e Chile. Em Montevidéu, Darcy leu o livro do Bonfim, o qual ele prefaciou e ressuscitou numa nova edição. Mas agora, no século XXI, penso que a identidade latino-americana do Brasil perderá sua preeminência.

\section{Como assim?}

O espaço latino-americano sofre o impulso de forças centrípetas. Resumindo bastante, é possível afirmar que o México foi engolido pelos Estados Unidos no âmbito da NAFTA, e o Chile e o Peru se conectam à Ásia, através do Tratado Transpacífico. 0 peso da China também puxa parte da América do Sul para o Pacífico. Paralelamente, o Atlântico Sul e as ligações transversais entre a África subsariana e a América do Sul voltaram a crescer depois da longa interrupção que vai do final do tráfico negreiro, em 1850, até a independência das colônias africanas, entre 1957 e 1975. Inclui-se aí também a articulação entre o Brasil e o Rio da Prata no quadro do Mercosul. Na realidade, a América Latina que sempre nos interessou e que mantém laços multisseculares com o Brasil é o núcleo inicial do Mercosul, são os países da bacia do Rio da Prata.

Entretanto, há entraves para o estudo do espaço sul-atlântico: as divisões disciplinares, como a que separa os americanistas dos africanistas. É preciso ressaltar que a área de estudos sul-atlânticos não substitui os estudos latino-americanistas. Este ponto foi salientado na inauguração da cátedra de estudos afro-latino-americanos, intitulada cátedra Edison Carneiro, em 2014, na UNILA, em Foz do Iguaçu. Da mesma forma, do outro lado do Atlântico, o foco está centrado nas nações africanas que formaram as nações sul-americanas, e não na África em 
geral. Num debate sobre o ensino da história da África no Brasil realizado na USP, uma pesquisadora trabalhando sobre o Mali disse que o Atlântico Sul não tinha muita coisa a ver com a pesquisa dela. E ela tinha razão. Há várias Áfricas e há regiões do continente que estavam fora do mundo atlântico.

Outro ponto a ser sublinhado é que o Atlântico Sul é bem maior que as relações bilaterais entre a Bahia e o golfo de Benim, por exemplo. E aí a rede Buenos Aires-Rio de Janeiro - Luanda - Lisboa tem um papel fundamental ao longo dos séculos. O Rio é um grande hub marítimo. É por isso que deveria haver no Rio, na FGV do Rio, um ensino estruturado sobre a História do Brasil no Atlântico Sul. O Rio é o grande porto do Atlântico Sul, e o Brasil é o país que tem a mais longa costa atlântica. Dou uma disciplina com esta temática na EESP e estou reunindo especialistas de diversas áreas interessados pelo tema no Centro de Estudos do Atlântico Sul. Alguns deles já eram ligados ao Centre d'Études du Brésil et de l'Atlantique Sud que eu dirigia na Paris-Sorbonne. Penso que esta área cultural constitui um quadro muito fecundo, do ponto de visto universitário e geopolítico, por causa do presente e do futuro, por causa da ligação com a África, sobretudo com a África subsaariana onde o crescimento demográfico é o mais rápido do mundo.

As conexões com a África vão bem além das iniciativas da diplomacia ou das empreiteiras brasileiras. Nos últimos anos, houve o ensino no secundário e a expansão das pesquisas universitárias brasileiras sobre a África, o vaivém dos pastores evangélicos, dos médios e pequenos empresários, técnicos que vão para Luanda e outras cidades africanas. Há ainda os estudantes africanos e sacoleiras angolanas que vêm para cá, para fazer compras na 25 de Março, em São Paulo. Há todo um circuito de trocas que está sendo retomado. Sem forçar os fatos, é possível dizer tem na África um soft power, conceito definido por Joseph Nye, que se refere à "influência branda" cultural, oposta ao hard power imposto pelas armas e pela coerção econômica.

\section{Notas}

1 Padre jesuíta nascido em 1908, foi professor e arqueólogo, responsável pela criação do Museu do Homem do Sambaqui.

2 Historiador e professor da Universidade do Distrito Federal e da USP. Publicou vários livros, entre eles Raízes do Brasil (1936), Cobra de vidro (1934), Monções (1945) e Visão do Paraíso (1958).

3 Escritor, crítico de cinema e militante político, responsável pela criação do primeiro curso de cinema da UnB em 1965.

4 Advogado e militante da Ação Libertadora Nacional (ALN) durante a ditadura militar no Brasil. 
5 Sociólogo e escritor brasileiro, fez parte do Secretariado da Organização das Nações Unidas e atualmente é pesquisador da Casa Rui Barbosa.

6 Economista, filho de Beatriz Ryff e de Raul Ryff, ambos militantes políticos presos nos anos 1930. Raul Ryff foi jornalista e secretário de Imprensa do governo João Goulart.

7 Fundador do Partido Comunista da Itália.

8 Fundador do Partido Comunista da Indochina, líder do movimento nacionalista vietnamita por mais de 30 anos e presidente do Vietnã do Norte de 1945 e 1969.

9 Diretor da Sciences Po de 1996 até seu falecimento em 2012.

10 A Escola dos Annales foi uma corrente historiográfica francesa lançada em finais da década de 1920 por Lucien Febvre e March Bloch em diálogo e contraposição direta com a Escola Metódica.

11 Os historiadores Duby, Vovelle e Agulhon especializaram-se, respectivamente, em História Medieval, estudos da Revolução Francesa, e História Contemporânea. 0 arqueólogo e historiador Paul Veyne especializou-se em História da Antiguidade Romana.

12 Mauro é especialista em História Econômica Latino Americana Contemporânea; Chaunu, professor de História Moderna na Sorbonne, foi precursor da História Quantitativa; Magalhães Godinho, professor, historiador e cientista social português, participou da Escola dos Annales; Vilar é historiador marxista especialista em estudos da Catalunha; Ruggiero Romano, historiador italiano, discípulo de Fernand Braudel, é especialista em História Americana.

13 Historiador norte-americano, um dos fundadores da História Econômica, especialista em estudos historiográficos espanhóis.

14 Professor e crítico literário.

15 Frade dominicano nascido em Fortaleza, frei Tito foi preso e torturado durante a ditadura militar. Foi banido do Brasil após um ano de cárcere e suicidou-se em 1974.

160 sociólogo Alain Touraine publicou trabalhos importantes sobre os movimentos sociais e trabalhistas no contexto da América Latina, e o também sociólogo Daniel Pécaut, especialista em problemas políticos da América Latina, publicou, entre outros, o livro Os intelectuais e a política no Brasil: entre o povo e a nação (1990).

17 Katia Mattoso (1932-2011) nasceu na Grécia e estudou Ciência Política na Universidade de Lausanne (Suíça) e na Sorbonne. Lecionou em universidades brasileiras e recebeu o título de doutora honoris causa na Universidade Federal da Bahia. Especialista em história econômica da Bahia e história da escravidão, publicou o livro Bahia Século 19 - Uma província no Império (1992) e foi professora de História do Brasil na Sorbonne até se aposentar em 1999.

18 L. F. de Alencastro, Que mentalidade é essa? Sobre a História das Mentalidades no Brasil, Novos Estudos CEBRAP, v. 33, p. 65-67, 1992.

19 Guillame le Maréchal ou Le meilleur chevalier du monde, publicado em 1984, retrata a vida do cavaleiro Guillame le Maréchal, um dos mais famosos de seu tempo.

20 Historiador francês e importante representante da Escola dos Annales. 
21 Jacques Le Goff, Roger Chartier, Jacques Revel (org.), La nouvelle histoire (Paris: C.E.P.L., 1978).

22 Historiador francês, Febvre foi co-fundador da Escola dos Annales. Martin Luther foi publicado em 1928.

230 livro de Marc Bloch, sobre a produção e difusão do mito do poder de cura dos monarcas, principalmente na França e na Inglaterra, foi publicado em 1924.

24 Fotógrafo, historiador e etnógrafo francês que passou grande parte da sua vida adulta no Brasil, Verger produziu trabalhos tanto documentais quanto fotográficos com foco nas relações culturais, sociais e religiosas entre as populações do Brasil e do continente africano afetadas pela escravidão transatlântica.

25 Fluxo e refluxo é um livro de Pierre Verger que apresenta o tema da escravidão na Bahia. Nele Verger aborda a questão dos fluxos econômicos gerados pelo mercado de escravos africanos na Bahia e apresenta fatores fundamentais para a consolidação da cultura e da identidade brasileiras que foram trazidos do continente africano junto com os escravos.

26 Philip Curtin foi um historiador norte-americano influente nos estudos sobre a escravidão transatlântica, pioneiro na utilização de métodos estatísticos modernos para calcular o fluxo de escravos na região. 0 debate acerca do número de escravos transportados é até hoje influenciado por seus trabalhos.

27 Charles Ralph Boxer, historiador inglês especialista nas atividades e rivalidades históricas europeias ao redor do globo antes dos anos 1800, desenvolveu estudos sobre questões ligadas à presença portuguesa e holandesa na Ásia nos séculos XVI e XVII.

28 Historiador, geógrafo e político brasileiro, autor, entre outras obras, de Formação do Brasil contemporâneo.

29 Historiador norte-americano especialista em história da América Latina.

30 Trata-se de 0 capital no século XXI, lançado em 2013, sucesso mundial de vendas.

31 Assim como o economista turco Daron Acemoglu, o economista e cientista político norte-americano James Robinson é co-autor do livro Por que as nações fracassam; Dora Costa, economista norte-americana, dedica-se à análise da desigualdade de renda e capital social.

32 Ângelo A. Carrara é historiador e professor do Departamento de História da Universidade Federal de Juiz de Fora; Alexandre Saes é economista e professor da Faculdade de Economia e Administração da Universidade de São Paulo; Leonardo Weller é economista e professor da Escola de Economia de São Paulo da Fundação Getúlio Vargas.

33 Michel Morineau foi um historiador francês, especialista em história econômica moderna, professor da Universidade de Paris XII - Val de Marne.

34 Historiador italiano, um dos representantes da corrente historiográfica da micro-história.

35 Pierre Paul Leroy-Beaulieu foi um economista liberal francês adepto do chamado Organicismo do Estado e de postura antimalthusiana. Fundou a revista L'Économiste Français.

36 Joaquim Pedro de Oliveira Martins foi um historiador e político português.

37 Historiador belga com trabalho dedicado especialmente à História e Antropologia de diversas regiões da África.

38 Paulo e Otília Arantes são filósofos brasileiros. 
39 Jean Devisse é historiador e é consagrado por seus estudos medievais e estudos sobre a África negra. Claude Meillassoux é antropólogo e se dedicou ao estudo da escravidão.

40 Evaldo Cabral de Mello, diplomata e historiador brasileiro, é especializado na história da ocupação holandesa em Pernambuco. John Manuel Monteiro, historiador brasileiro, é especialista em história indígena.

41 Historiador e ensaísta francês, foi membro da Academia Francesa.

42 Historiador francês com importante trabalho sobre a Revolução Francesa.

43 Albert Soboul foi professor de História da Sorbonne a partir de 1967. Influenciou com a sua obra os estudos marxistas sobre a Revolução Francesa e até hoje seus trabalhos são referência nesse campo de estudo.

44 Médico, sociólogo e historiador brasileiro.

45 Comissão Econômica para América Latina e Caribe, criada em 1948. 